\title{
ISOLATION OF DIPHTHEROID BACILLI FROM SYNOVIAL MEMBRANE AND FLUID IN RHEUMATOID ARTHRITIS*
}

\author{
BY \\ S. M. STEWART, W. R. M. ALEXANDER, AND J. J. R. DUTHIE \\ From the Department of Bacteriology, University of Edinburgh, and the \\ Rheumatic Diseases Unit, Northern General Hospital, Edinburgh
}

The view that rheumatoid arthritis might be caused by an infective agent has long been held. Although various bacteria have been isolated in the past, none has been shown to cause the disease. Much of this work was done in the 1930s and was extensively reviewed by $\mathbf{P}$. S. Hench and his fellow editors of the first eight "Rheumatism Reviews" (1935-1941) published collectively in 1961. In more recent years the basis for the view has varied from purely theoretical, intuitive considerations (Bauer, Clark, and Dienes, 1951; Christian, 1964; Sharp, 1964; British Medical Journal, 1965; Hamerman, 1966; Ford, 1968) to circumstantial evidence of an infective agent in the synovial fluid (Duthie, 1964; Duthie, Alexander, and Stewart, 1965). Hill (1968) suggested that the available evidence in favour of an infective element in rheumatoid arthritis included the occasional fever, leucocytosis, lymphadenopathy, loss of weight, raised erythrocyte sedimentation rate, and the presence of warm, swollen joints. To these attributes may be added the occasional acute onset of the disease with signs or symptoms of an infection. Hill, however, also stressed that the presence of rheumatoid factor in the serum was equally consistent with an autoimmune response and with a chronic infection; he suggested that "if microorganisms play an aetiological role in rheumatoid arthritis, it seems likely that this will prove to be indirect and mediated through a disturbed immune response". In this context it may be noted that rheumatoid factor reacting with sensitized sheep erythrocytes and/or gamma-globulin-coated particles may be present in illnesses demonstrably caused by bacteria or viruses (Howell, Malcolm, and Pike, 1960; Hall, 1961; Alexander and McCarthy, 1966). A similar factor can be produced in rabbits hyperimmunized with killed bacteria (Christian, 1961; Abruzzo and Christian, 1961). Svartz

* Reprints are available from Dr. S. M. Stewart, Wellcome Laboratory, City Hospital, Greenbank Drive, Edinburgh, EH10 5SB.
(1961) claimed to have induced formation of rheumatoid factor in rabbits and rats by injection of bacteria cultured from the nasopharynx of patients with rheumatoid arthritis.

Similarities have been noted between swine arthritis caused by mycoplasmata (Sharp and Riggs, 1967; Ross and Switzer, 1968) or Erysipelothrix (Collins and Goldie, 1940) and rheumatoid arthritis in man. Such similarities have led these authors to suggest that there may be an infective element in rheumatoid arthritis.

Attempts to isolate viruses from the synovial fluid or synovial membrane of patients with rheumatoid arthritis have failed so far (Utz, Phelps, and Smith, 1959; Claus, McEwen, Brunner, and Tsamparlis, 1964; Ford and Oh, 1965; Barnett, Balduzzi, Vaughan, and Morgan, 1966; Waller, Sever, Curry, and Gilkeson, 1966). However, the methods used would probably have detected only cytocidal viruses and not those integrated with the genome of the synovial cell or present in some other "non-producing' state.

Attention may also be drawn to the observation of Schachter, Jones, Barnes, Engleman, and Meyer(1966), who isolated Bedsonia (Chlamydia) agents from the urethra, conjunctiva, or joints of patients, most of whom suffered from Reiter's disease but some of whom showed features suggestive of rheumatoid arthritis. Schachter (1967) also reported the isolation of two strains of Bedsonia from established cases of rheumatoid arthritis.

A number of workers have isolated mycoplasmata (Sabin and Warren, 1940; Arai, Ishikawa, and Hotta, 1964; Bartholomew and Himes, 1964; Bartholomew, 1965, 1966; Williams, 1968). The strains isolated belonged to a variety of species (M. fermentans, M. hominis, M. hyorhinis). Brown, Bailey, Felts, and Clark (1966) reported the finding of complement-fixing antibodies to various mycoplasmata in synovial fluid from "arthritic patients". 
The work described in this communication was originally started in an attempt to culture mycoplasmata from the joints of patients with rheumatoid arthritis. Only one strain, identified as $M$. hyorhinis, was isolated and, as unheated swine serum was used in the medium, it may have been a contaminant from this source. However, during this work, bacteria were grown on some plates. At first these cultures, mostly diphtheroids, were discarded as contaminants. Later it was noticed that diphtheroid bacilli were more often isolated from the specimens from patients with rheumatoid arthritis. A preliminary report of these findings was published (Duthie, Stewart, Alexander, and Dayhoff, 1967), but the numbers were not large enough to be subjected to statistical analysis. In an extension of this work (Stewart, 1967), similar isolation rates of diphtheroids were reported without a full discussion of the possible explanation of the findings.

The results of examining a larger series of specimens from patients with rheumatoid arthritis and other articular diseases are presented below. Technical details of the methods used are given and possible explanations of the observations are discussed.

\section{Material and Methods}

78 specimens of synovial membrane removed at operation and 126 aspirates of synovial fluid were examined from 179 patients with "definite" rheumatoid arthritis according to the diagnostic criteria of the American Rheumatism Association (1959). Other material included fifteen fluids from twelve patients with Reiter's disease, four membranes and 23 fluids from 25 patients with osteoarthrosis, and sixteen membranes and fourteen fluids from thirty patients with other inflammatory, traumatic, or degenerative joint disease. Blood cultures were examined in an effort to test materials of comparable nutrient and cellular properties to those of rheumatoid synovium. 84 of these cultures were from 75 patients with definite rheumatoid arthritis and sixteen were from thirteen patients with Reiter's disease. Blood cultures from 38 patients with other conditions and from twelve healthy individuals were also examined.

All the specimens of membranes were obtained from operations carried out in the same theatre. The membranes were generally obtained immediately the synovial cavity was opened. There was no difference in the average time taken to obtain the specimens of rheumatoid and control tissue. The amount of membrane used for inoculation varied according to the material available.

All specimens of fluid and blood were obtained in the Rheumatic Diseases Unit. $10 \mathrm{ml}$. volumes of fluid and blood were cultured in the majority of cases.

\section{Techniques of Bacterial Culture}

Details of the media used are given in the Appendix; none contained antibiotics or other inhibitory substances.

The clinical diagnosis was not known to the bacteriologist at the time of examination of the specimens which were identified only by a laboratory number. This principle of the "blind" approach could not be applied to the examination of smears because those from rheumatoid specimens were more cellular than those from noninflamed sites. This limitation applied also to cultures of rheumatoid membrane, most of which could be seen to contain many cells. It was not possible to discriminate between fluids whether from rheumatoid or other sources.

Synovial Membranes.--Specimens were collected in dry, sterile, $28 \mathrm{ml}$. screw-capped containers. They were kept at $4^{\circ} \mathrm{C}$. for not more than 5 hours until transported to the laboratory. On receipt they were chopped up finely with sterile scissors and placed into sterile, $7 \mathrm{ml}$. screwcapped bottles. When cellular tissue was present, this was filleted off and used for culture. If no appreciable amount of such tissue was present, as in the meniscectomy specimens, the whole sample was used. This procedure may have resulted in a slightly longer time being taken to prepare rheumatoid membranes for culture.

To the chopped membrane was added approximately $5 \mathrm{ml}$. of a liquid medium. The membrane-medium mixture was then shaken and incubated at $37 \mathrm{C}$. When the Eagle-Hanks medium (Medium 1) was used, the medium tended to become acid due to the metabolism of the cells; therefore the supernatant fluid was removed twice weekly, leaving approximately $1 \mathrm{ml}$. of medium over the chopped membrane. This was used to inoculate PPLO agar plates (Medium 5). Fresh medium was then added and the membrane suspension re-incubated. When heated blood broth (Medium 3) or sodium chloride PPLO broth (Medium 4) was used, sub-cultures were done weekly on to the corresponding agar (Medium 6 or 7 respectively) without removing the medium over the membrane. Initially subcultures from the liquid media were made over a period of 7 weeks, later reduced to 3 weeks.

The solid medium plates were incubated at $37 \mathrm{C}$. in an atmosphere of 10 per cent. carbon dioxide. In early experiments the plates were read twice weekly and were only discarded as negative after 7 weeks' incubation. Later the plates were read weekly and discarded after 3 weeks. All solid medium cultures were read macroscopically and, if negative, microscopically at a magnification of $\times 40$. Many of the diphtheroid colonies were detected only under the microscope.

Synovial Fluids and Blood Cultures.-Approximately $10 \mathrm{ml}$. of synovial fluid or venous blood were added direct from the syringe used for aspiration to $10 \mathrm{ml}$. of liquid medium (Medium 2, 3 or 4) in a $28 \mathrm{ml}$. screw-capped bottle. 42 specimens of synovial fluid and 54 of blood were cultured in both supplemented heated blood liquid medium (Medium 3) and sodium chloride PPLO broth 
(Medium 4). The remaining specimens were inoculated into supplemented double-strength PPLO broth (Medium 2). The mixture was incubated at $37^{\circ} \mathrm{C}$. and subcultured on to PPLO agar (Medium 5), heated blood agar (Medium 6), or sodium chloride agar (Medium 7), depending on the original liquid medium used. The subcultures were made 3 to 5 days after inoculation of the broth and weekly thereafter for 3 weeks. The plates were incubated at $37^{\circ} \mathrm{C}$. in an atmosphere of 10 per cent. carbon dioxide. They were examined after 24 to 48 hours and then weekly for 3 weeks before being discarded as negative.

Control Medium.-One bottle of uninoculated medium was included with each batch of membranes and fluids and was incubated and subcultured in the same way and using the same batches of media as those for the specimens.

Sterility of Human Serum.-40 ml. volumes of human serum from four batches, each representing pooled serum from 4 pints of blood, were cultured in $140 \mathrm{ml}$. of Medium 8 and subcultured in the same way as the fluids. These batches were tested during the last 3 months of the investigation which lasted 37 months in all.

\section{Impression Smears}

These were prepared from cut edges of the membranes from 33 patients with rheumatoid arthritis, three with osteoarthrosis, one with an internal derangement of the knee joint, and six on whom a meniscectomy was performed. The smears were fixed in methanol for 10 minutes, stained for 30 minutes with 8 per cent. Giemsa (Gurr's improved, R66) and differentiated with tap water.

\section{Complement-Fixation Tests}

Antigens were prepared by growing the organisms in supplemented PPLO broth (Medium 8) for 5 days. The growth was concentrated by centrifugation, washed three times in saline and then heated at $100^{\circ} \mathrm{C}$. for 30 minutes. The method used for the tests was that of Bradstreet and Taylor (1962).

\section{Results}

Isolation of Diphtheroid Bacilli from Synovial Membranes, Synovial Fluids, and Blood Cultures

The frequency of isolation of diphtheroid bacilli from synovial membranes, synovial fluids, and blood cultures is shown in Tables I, II, and III respectively.

Diphtheroids were isolated from 27 per cent. of the 78 membranes examined from patients with rheumatoid arthritis as compared with none of the twenty membranes from patients with other conditions. This difference is statistically significant $(P<0.05)$.

Twelve (10 per cent.) of the 126 specimens of synovial fluid from patients with rheumatoid arthritis and three of the sixteen specimens from patients with Reiter's disease yielded diphtheroids.
TABLE I

ISOLATION RATE OF DIPHTHEROID BACILLI FROM SYNOVIAL MEMBRANES

\begin{tabular}{l|c|c|c|c}
\hline \multicolumn{1}{c|}{ Diagnosis } & $\begin{array}{c}\text { No. of } \\
\text { Patients }\end{array}$ & Isolated & $\begin{array}{c}\text { Diphtheroids } \\
\text { isolated }\end{array}$ & $\begin{array}{c}\text { Total No. of } \\
\text { Membranes } \\
\text { Examined }\end{array}$ \\
\cline { 2 - 5 } $\begin{array}{c}\text { Rheumatoid } \\
\text { Arthritis }\end{array}$ & 71 & $\begin{array}{c}21(27 \\
\text { per cent.) }\end{array}$ & 57 & 78 \\
\hline $\begin{array}{c}\text { Other } \\
\text { Conditions* }\end{array}$ & 20 & 0 & 20 & 20 \\
\hline Total & 91 & 21 & 77 & 98 \\
\hline
\end{tabular}

$(P<0.05)$

*Diagnoses: Torn menisci and other internal derangements of the knee Osteoarthrosis Osteochondritis

TABLE II

ISOLATION RATE OF DIPHTHEROID BACILLI FROM SYNOVIAL FLUID

\begin{tabular}{l|c|c|c|c}
\hline \multicolumn{1}{c|}{ Diagnosis } & $\begin{array}{c}\text { No. of } \\
\text { Patients }\end{array}$ & \multicolumn{2}{|c|}{ Diphtheroids } & $\begin{array}{c}\text { Total No. } \\
\text { of Fluids } \\
\text { Examined }\end{array}$ \\
\cline { 2 - 4 } $\begin{array}{c}\text { Rheumatoid } \\
\text { Arthritis }\end{array}$ & 108 & $\begin{array}{c}12(10 \\
\text { per cent.) }\end{array}$ & 114 & 126 \\
\hline $\begin{array}{c}\text { Reiter's } \\
\text { Disease }\end{array}$ & 12 & $\begin{array}{c}3(20 \\
\text { per cent.) }\end{array}$ & 12 & 15 \\
\hline $\begin{array}{c}\text { Other } \\
\text { Conditions* }\end{array}$ & 35 & $\begin{array}{c}1(3 \\
\text { per cent.) }\end{array}$ & 36 & 37 \\
\hline Total & 155 & 16 & 162 & 178 \\
\hline
\end{tabular}

*Diagnoses: Osteoarthrosis Psoriatic arthropathy 2 Polymyalgia rheumatica 3 Gout Still's disease Rheuratic fever Ankylosing spondylitis Erythema nodosum Possible rheumatoid arthritis

4
3
2
1
1
1
1
1

TABLE III

ISOLATION RATE OF DIPHTHEROID BACILLI FROM BLOOD CULTURES

\begin{tabular}{l|c|c|c|c}
\hline \multirow{2}{*}{ Diagnosis } & $\begin{array}{c}\text { No. of } \\
\text { Patients }\end{array}$ & Isolated & $\begin{array}{c}\text { Diphtheroids } \\
\text { isolated }\end{array}$ & $\begin{array}{c}\text { Total No. of } \\
\text { Blood } \\
\text { Cultures } \\
\text { Examined }\end{array}$ \\
\cline { 2 - 4 } & 75 & $\begin{array}{c}7(8 \\
\text { per cent. })\end{array}$ & 77 & 84 \\
\hline $\begin{array}{c}\text { Rheumatoid } \\
\text { Arthritis }\end{array}$ & 13 & $\begin{array}{c}3(19 \\
\text { per cent. })\end{array}$ & 13 & 16 \\
\hline $\begin{array}{c}\text { Reiter's } \\
\text { Disease }\end{array}$ & 38 & 0 & 38 & 38 \\
\hline $\begin{array}{c}\text { Other } \\
\text { Conditions* }\end{array}$ & 12 & 0 & 12 & 12 \\
\hline Healthy & 138 & 10 & 140 & 150 \\
\hline Individuals & Total & 13 & \\
\hline
\end{tabular}

*Diagnoses as listed in Table IV

From the remaining specimens only one isolate, from the synovial fluid of a patient with possible rheumatoid arthritis, was obtained. 
Seven ( 8 per cent.) of the 84 blood cultures from patients with rheumatoid arthritis and three (19 per cent.) of sixteen cultures from patients with Reiter's disease yielded cultures of diphtheroid bacilli. Diphtheroid bacilli were not isolated from the blood cultures of 28 patients with other diseases (Table IV), nor from twelve healthy individuals.

TABLE IV

"Other Conditions" referred to in Table III

\begin{tabular}{l|c}
\hline \multicolumn{1}{c|}{ Diagnosis } & No. of Patients \\
\hline Osteoarthrosis & 14 \\
Ankylosing spondylitis & 7 \\
Polymyalgia rheumatica & 3 \\
Possible rheumatoid arthritis & 3 \\
Psoriatic arthropathy & 1 \\
Intermittent hydrarthrosis & 1 \\
Erythema nodosum & 1 \\
Carcinoma of prostate & 1 \\
Tendinitis & 1 \\
Systemic lupus erythematosus & 1 \\
Lupoid hepatitis & 1 \\
Intervertebral disc disease & 1 \\
Chondrocalcinosis & 1 \\
Psychoneurosis & \\
\hline
\end{tabular}

Isolation Rate of Staphylococci and Other Organisms

Tables V, VI, and VII show the isolation rates of organisms other than diphtheroids from the membranes, fluids, and blood cultures respectively. Two

TABLE V

ISOLATION RATE OF STAPHYLOCOCCI FROM SYNOVIAL MEMBRANES

\begin{tabular}{l|c|c|c|c}
\hline \multicolumn{1}{c|}{ Diagnosis } & $\begin{array}{c}\text { No. of } \\
\text { Patients }\end{array}$ & \multicolumn{2}{|c|}{ Staphylococci } & $\begin{array}{c}\text { Total No. of } \\
\text { Isolated } \\
\text { Eembranes } \\
\text { Examined }\end{array}$ \\
\hline $\begin{array}{c}\text { Rheumatoid } \\
\text { Arthritis }\end{array}$ & 71 & $\begin{array}{r}9(11 \cdot 5 \\
\text { per cent.) }\end{array}$ & 69 & 78 \\
\hline $\begin{array}{c}\text { Other } \\
\text { Conditions }\end{array}$ & 20 & $\begin{array}{c}3(15 \\
\text { per cent.) }\end{array}$ & 17 & 20 \\
\hline Total & 91 & 12 & 86 & 98 \\
\hline
\end{tabular}

$\left(x^{2}=0.0015 ; 0.95>P>0.90\right)$

*For diagnoses see footnote to Table I.

TABLE VI

ISOLATION RATES OF STAPHYLOCOCCI PLUS COLIFORMS FROM SYNOVIAL FLUID

\begin{tabular}{l|c|c|c|c}
\hline Diagnosis & $\begin{array}{c}\text { No. of } \\
\text { Patients }\end{array}$ & $\begin{array}{c}\text { Staphylococci or } \\
\text { Coliforms }\end{array}$ & $\begin{array}{c}\text { Total No. of } \\
\text { Fluids } \\
\text { Examined }\end{array}$ \\
\hline $\begin{array}{c}\text { Rheumatoid } \\
\text { Arthritis }\end{array}$ & 108 & $\begin{array}{c}20(16 \\
\text { per cent.) }\end{array}$ & 106 & 126 \\
\hline $\begin{array}{c}\text { Reiter's } \\
\text { Disease }\end{array}$ & 12 & $\begin{array}{c}3(20 \\
\text { per cent.) }\end{array}$ & 12 & 15 \\
\hline $\begin{array}{c}\text { Other } \\
\text { Conditions* }\end{array}$ & 35 & $\begin{array}{c}9(24 \\
\text { per cent. })\end{array}$ & 28 & 37 \\
\hline Total & 155 & 32 & 146 & 178 \\
\hline
\end{tabular}

$\left(x^{2}=0.5026 ; 0.70>P>0.50\right)$

*For diagnoses see footnote to Table II.
TABLE VII

ISOLATION RATE OF STAPHYLOCOCCI FROM BLOOD CULTURES

\begin{tabular}{l|c|c|c|c}
\hline \multicolumn{1}{|c|}{ Diagnosis } & $\begin{array}{c}\text { No. of } \\
\text { Patients }\end{array}$ & Isolated & $\begin{array}{c}\text { Sot } \\
\text { isolated }\end{array}$ & $\begin{array}{c}\text { Total No. of } \\
\text { Blood } \\
\text { Cultures } \\
\text { Examined }\end{array}$ \\
\hline $\begin{array}{c}\text { Rheumatoid } \\
\text { Arthritis }\end{array}$ & 75 & $\begin{array}{c}7(9 \\
\text { per cent.) }\end{array}$ & 77 & 84 \\
\hline $\begin{array}{c}\text { Reiter's } \\
\text { Disease }\end{array}$ & 13 & $\begin{array}{c}2(12 \\
\text { per cent.) }\end{array}$ & 14 & 16 \\
\hline $\begin{array}{c}\text { Other } \\
\text { Conditions* }\end{array}$ & 38 & $\begin{array}{c}4(10 \\
\text { per cent.) }\end{array}$ & 34 & 38 \\
\hline $\begin{array}{c}\text { Healthy } \\
\text { Individuals }\end{array}$ & 12 & 0 & 12 & 12 \\
\hline Total & 138 & 13 & 137 & 150 \\
\hline
\end{tabular}

* For diagnoses see Table IV

of the cultures from fluids were coliforms. The remaining bacteria were staphylococci, which were isolated with similar frequency from non-rheumatoid and from rheumatoid material.

\section{Control Broths and Cultures of Human Serum}

Three strains of diphtheroids were isolated from 106 control uninoculated broth cultures. No strains of diphiheroids were isolated from the four cultures of bulk medium containing human serum from four different batches.

Effect of different media on the isolation of diphtheroids from synovial membranes and fluids.-The use of different media listed in the Appendix did not affect the frequency of isolation of diphtheroids from the membranes, nor from the fluids.

Correlation of the results of the isolation of diphtheroids and the results of the sensitized sheep cell test (Table VIII).--Isolations from membranes and from fluids were made more frequently from sero-positive than from sero-negative patients. The difference was statistically significant $(P<0.001)$.

TABLE VIII

CORRELATION OF THE RESULTS OF THE SENSITIZED SHEEP CELL TEST AND ISOLATION OF DIPHTHEROID BACILLI IN PATIENTS WITH RHEUMATOID ARTHRITIS*

\begin{tabular}{|c|c|c|c|}
\hline \multirow{2}{*}{$\begin{array}{l}\text { Sensitized Sheep } \\
\text { Cell Test }\end{array}$} & \multirow{2}{*}{$\begin{array}{l}\text { Total No. } \\
\text { of Patients }\end{array}$} & \multicolumn{2}{|c|}{$\begin{array}{l}\text { Isolations from Membranes } \\
\text { or Fluids }\end{array}$} \\
\hline & & Diphtheroids & No diphtheroids \\
\hline $\begin{array}{l}\text { Positive } \\
\text { Negative }\end{array}$ & $\begin{array}{l}92 \\
57\end{array}$ & $\begin{array}{r}28 \\
3\end{array}$ & $\begin{array}{l}64 \\
54\end{array}$ \\
\hline Total & $149 t$ & $31 \ddagger$ & 118 \\
\hline
\end{tabular}

$\chi^{2}=12.06 ; \mathrm{P}<0.001(n=1)$.

*Excluding specimens from which staphylococci were isolated.

+In three patients the sensitized sheep cell test was not done.

tWhen more than one specimen from an individual was examined, result included in this column if a diphtheroid was isolated on at least one occasion. 
Correlation of the incidence of isolation of diphtheroids and various clinical factors (Table IX).There was no obvious correlation between the isolation of diphtheroid bacilli and the age or sex of the patient or clinical features of the disease.

Comparison of the isolations of diphtheroids from synovial fluids and blood cultures.-In 66 patients synovial fluid and blood were cultured in parallel. In two patients diphtheroids were isolated from both specimens. In six, diphtheroids were isolated only from the blood, and in a further six they were isolated only from synovial fluid. No diphtheroids were isolated from either specimen in the remaining $\mathbf{5 2}$ cases.

\section{Impression Smears from Membranes}

In fourteen of the 33 membranes from patients with rheumatoid arthritis, small basophilic granules were seen within the cytoplasm of some mononuclear cells. An example is shown in the Figure. No granules were seen in any of the other specimens examined. There was no correlation between the presence of the granules and subsequent isolation of diphtheroid bacilli.

TABLE IX

CLINICAL CHARACTERISTICS OF PATIENTS WITH RHEUMATOID ARTHRITIS FROM WHOM SYNOVIAL MEMBRANES OR FLUIDS WERE EXAMINED*

\begin{tabular}{|c|c|c|c|c|c|c|c|c|c|c|c|}
\hline \multirow{2}{*}{ Specimens } & \multirow{2}{*}{ Culture Results } & \multirow{2}{*}{$\begin{array}{c}\text { Total No. of } \\
\text { Patients }\end{array}$} & \multicolumn{2}{|c|}{ Age (yrs) } & \multicolumn{2}{|c|}{ Sex } & \multicolumn{2}{|c|}{$\begin{array}{c}\text { Duration of Illness } \\
\text { (yrs) }\end{array}$} & \multicolumn{3}{|c|}{$\begin{array}{l}\text { Sensitized Sheep } \\
\text { Cell Test }\end{array}$} \\
\hline & & & Range & Mean & Male & Female & Range & Mean & + ve & -ve & $\begin{array}{l}\text { Not } \\
\text { Done }\end{array}$ \\
\hline \multirow{2}{*}{ Membranes } & Diphtheroids & 21 & $25-69$ & $51 \cdot 0$ & 6 & 15 & $2->20$ & $9 \cdot 1$ & 17 & 2 & 2 \\
\hline & No Diphtheroids & 41 & $20-66$ & $51 \cdot 0$ & 9 & 32 & $1 \cdot 5-26$ & $9 \cdot 3$ & 19 & 21 & 1 \\
\hline \multirow{2}{*}{ Fluids } & Diphtheroids & 12 & $20-74$ & $52 \cdot 0$ & 4 & 8 & $<1 \cdot 0-20$ & $5 \cdot 8$ & 11 & 1 & 0 \\
\hline & No Diphtheroids & 78 & $20-78$ & $55 \cdot 8$ & 36 & 42 & $<1 \cdot 0->20$ & $8 \cdot 9$ & 45 & 33 & 0 \\
\hline
\end{tabular}

*Patients from whose specimens staphylococci were isolated have been excluded.

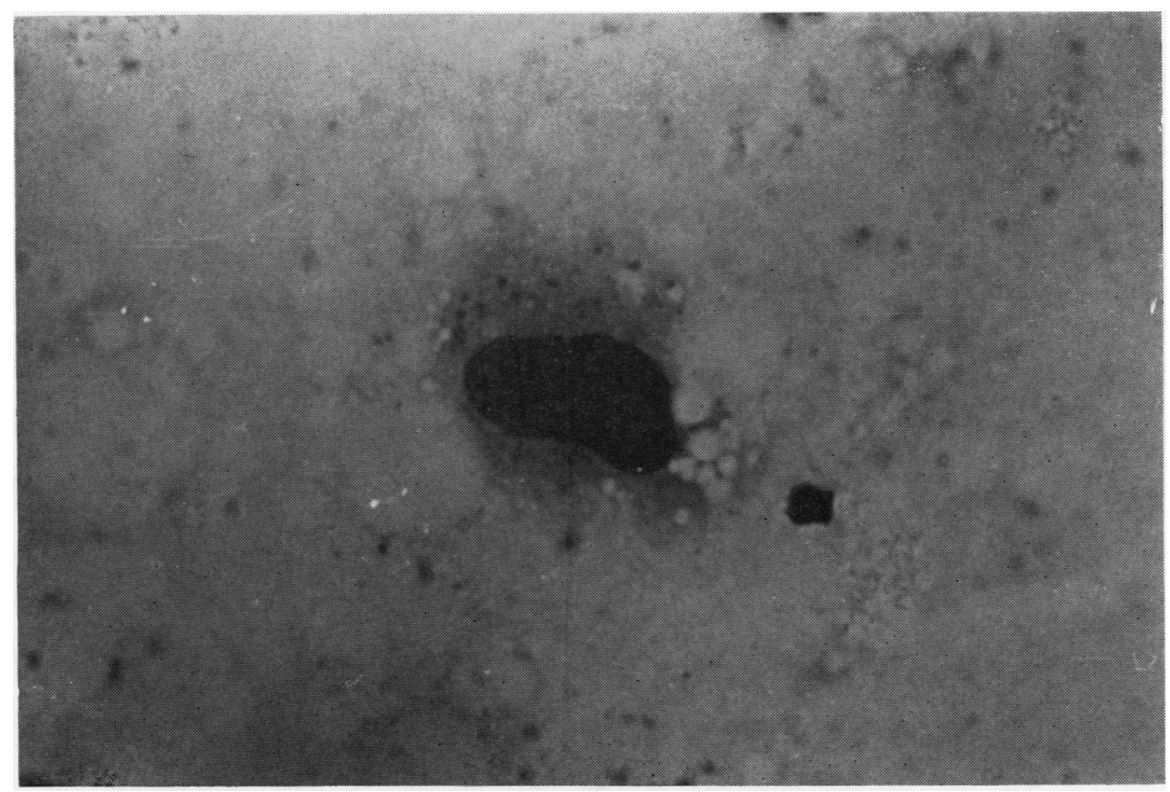

Figure.-Impression smear of a membrane from a patient with rheumatoid arthritis. Stained Giemsa. Note $\begin{aligned} & \text { presence of intracellular } \\ & \text { basophilic granules. }\end{aligned}$ $\times 1,500$. 


\section{Bacteriological Properties of the Isolates}

Some bacteriological properties of the isolates are shown in Table $\mathrm{X}$ and compared with those of standard strains of $C$. hofmanii (NCTC 231), $C$. bovis (NCTC 3224), C. pyogenes (NCTC 6448), and C. xerosis (NCTC 9755). All the strains isolated were Gram-positive bacilli or coccobacilli. The majority were non-haemolytic on blood agar, sensitive to bacitracin, non-motile, and were producers of catalase. They were not, however, a homogenous group.

\section{Animal Pathogenicity}

Two strains were tested for pathogenicity by inoculating approximately $10^{8}$ organisms in a saline suspension subcutaneously into mice. Four strains were tested by giving a similar dose intravenously into rabbits. Two drops of a suspension containing $10^{7}$ organisms of two strains were dropped on to the corneae of guinea-pigs. There was no evidence of disease in any of the animals.

\section{Complement-fixation Tests}

21 sera from patients with rheumatoid arthritis were tested against antigen from one of the isolates. One serum gave a titre of 1 in 10 and one of 1 in 20; the remainder gave titres of less than 1 in 10.

\section{Discussion}

There are few reports of the isolation of bacteria from tissues of patients with rheumatoid arthritis. Cadham (1932) claimed to have isolated diphtheroid bacilli from lymph nodes of 27 out of 34 cases. Hill, McCormick, Greenbury, Morris, and Kenningdale (1967), using a coverslip culture technique, reported the isolation of diphtheroid organisms from the synovial fluid of fifteen of thirty patients with rheumatoid arthritis. They also cultured one strain from the pleural fluid from a patient with rheumatoid arthritis, two from synovial fluids from patients with psoriasis, and four from six synovial fluids from patients with osteoarthrosis. One strain was isolated from one of 45 subcultures from uninoculated blood agar plates and one strain from one of 22 samples of uninoculated tissue culture medium. The authors concluded that the results should be interpreted more with caution than optimism. Dayhoff (1967), in collaboration with the present authors, but working in a different laboratory, isolated diphtheroid organisms from five of 43 antibiotic-free cultures of cells from rheumatoid synovial fluid. Unfortunately, adequate control material was not available.

There seem to be three possible interpretations of the isolation of diphtheroid organisms from patients with rheumatoid arthritis and Reiter's disease:

(1) They may be contaminants introduced at the time of collection of the samples or at the time of examination of the specimen in the laboratory, either from components of the media or from the air.

(2) They may be present in the joints but unrelated to the disease ("passengers").

(3) They may play a pathogenic role ("drivers").

Each of these possibilities will be discussed.

Diphtheroid organisms are common skin contaminants and might easily be introduced at any stage between collection of the specimen and final subculture. However, if this were so, it is surprising that diphtheroids were not isolated more frequently from specimens obtained from patients with noninflammatory articular disease. The surgical team and theatre environment were the same for the collection of specimens from patients with rheumatoid arthritis and from those with other conditions, as were the aspiration techniques used to obtain synovial fluids and blood for culture. There is no

\begin{tabular}{|c|c|c|c|c|c|c|c|c|}
\hline \multirow{2}{*}{ Source } & \multirow{2}{*}{$\begin{array}{l}\text { Total No. of } \\
\text { Strains }\end{array}$} & \multicolumn{2}{|c|}{ Metachromatic Granules } & \multicolumn{3}{|c|}{ Blood Agar Haemolysis } & \multicolumn{2}{|c|}{ Bacitracin } \\
\hline & & Present & Absent & $a$ & $\beta$ & $\gamma$ & Sensitive & Resistant \\
\hline Synovial membranes & 19 & 9* & 9* & 3 & $\mathbf{0}$ & 16 & 17 & 2 \\
\hline Synovial fluids & 8 & 7 & 1 & 1 & 0 & 7 & 6 & 2 \\
\hline Blood cultures & 2 & 1 & 1 & 0 & $\mathbf{0}$ & 2 & 2 & 0 \\
\hline $\begin{aligned} \text { Standard Strains: } & \text { C. hofmanii } \\
& \text { C. xerosis } \\
& \text { C. bovis } \\
& \text { C. pyogenes }\end{aligned}$ & $\begin{array}{l}1 \\
1 \\
1 \\
1\end{array}$ & $\begin{array}{l}0 \\
0 \\
\text { not } \mathrm{e} \\
\text { not } \mathrm{e}\end{array}$ & $\begin{array}{r}1 \\
\text { ined } \\
\text { ined }\end{array}$ & $\begin{array}{l}0 \\
0 \\
1 \\
1\end{array}$ & $\begin{array}{l}\mathbf{0} \\
0 \\
0 \\
0\end{array}$ & $\begin{array}{l}1 \\
1 \\
0 \\
0\end{array}$ & $\begin{array}{l}1 \\
1 \\
0 \\
0\end{array}$ & $\begin{array}{l}0 \\
0 \\
1 \\
1\end{array}$ \\
\hline
\end{tabular}

*One strain not examined 
definite evidence that the specimens of membrane were exposed to possible contamination in the theatre for longer in the rheumatoid cases than in the nonrheumatoid controls. These observations seem to be against the possibility of contamination during the collection of the specimens. There remains the possibility of contamination in the laboratory. Three of 106 batches of control, uninoculated media did yield diphtheroids. Unfortunately, the use of such control media, tested in parallel with each batch of specimens, does not completely rule out the possibility of the organism being introduced with constituents of the media, because these organisms grow poorly on primary isolation. Also the nutrient value of the inoculated media might be enhanced by the presence of cellular material. Finally, there is the possibility that specimens from rheumatoid patients have been manipulated to a greater extent than the control material when preparing them for culture. Klieneberger-Nobel (1962) discussed an analogous difficulty in the interpretation of experiments on the possible transformation of mycoplasmata into diphtheroids, and pointed out how difficult it was to ensure that test and control circumstances were the same.

On balance, the infrequency of positive cultures other than from patients with rheumatoid arthritis or Reiter's disease suggests that the diphtheroids were probably not environmental contaminants. One other observation suggesting that the diphtheroids were not contaminants derives from the frequency of isolation of staphylococci and coliforms. These organisms were cultured as frequently from non-rheumatoid as from rheumatoid specimens and may be taken as an indicator of the risk from aerial contamination.

If it is accepted that the organisms cultured came in fact from joints, the problem of their pathogenicity still remains. They may have invaded or been scavenged by macrophages, playing no role in initiation or perpetuation of the disease. They may be "passengers" or opportunists taking advantage of the deranged physiology of the joints, as has been suggested with diphtheroids isolated from lymph nodes of patients suffering from lymphadenoma (Wilson and Miles, 1964), but of such a low pathogenicity that they do not multiply extensively or evoke a pyogenic reaction.

In considering the possible role of diphtheroids as aetiological agents, it may be conjectured that they are exogenous antigens in the synovium, or that they may act, like Corynebacterium parvum, by altering the mechanisms controlling immunological tolerance (Pinckard, Weir, and McBride, 1968). Indeed, preliminary experiments have shown that one of the cultures from a patient with rheumatoid arthritis had a similar effect to $C$. parvum in preventing induction of tolerance to bovine serum albumin in rabbits and mice (Weir, 1969). If the diphtheroids are able to alter immune tolerance in patients with rheumatoid arthritis, it is perhaps surprising that humoral antibody to intact bacilli has not yet been detected. Possibly the organisms are present as intracellular protoplasts in the synovial cells and have lost the cell wall on which most serological reactions would depend. It is known that living diphtheroids inoculated into cultures of rheumatoid synovial cells become intracellular and lose their cell wall as demonstrated by electron microscopy (Alexander, Stewart, and Duthie, 1968). Although organisms have been recovered in colonial form from such cell cultures as long as 21 days after infection, it is still possible that the organisms recovered may have multiplied from a few bacteria which had remained extracellular. It may be that the intracellular granules seen in many of the impression smears from membranes from patients with rheumatoid arthritis represent this small intracellular form, but it has not been possible to correlate the presence of such granules with the isolation of diphtheroid bacilli.

$\mathbf{X}$

DIPHTHEROIDS

\begin{tabular}{|c|c|c|c|c|c|c|c|c|}
\hline \multicolumn{2}{|c|}{ Staph. pyogenes } & \multicolumn{2}{|c|}{ Glucose Fermentation } & \multirow{2}{*}{$\begin{array}{l}\text { Motility } \\
25^{\circ} \text { and } 37^{\circ} \\
\text { negative }\end{array}$} & \multicolumn{2}{|c|}{ Retention of Dienes Stain } & \multicolumn{2}{|c|}{ Catalase } \\
\hline Satellitism & No Satellitism & + ve & -ve & & +ve & -ve & + ve & -ve \\
\hline 1 & 18 & 8 & 11 & 19 & 6 & 13 & 16 & 3 \\
\hline $\mathbf{0}$ & 8 & 1 & 7 & 8 & 4 & 4 & 7 & 1 \\
\hline $\mathbf{0}$ & 2 & 1 & 1 & 2 & 1 & 1 & 2 & 0 \\
\hline $\begin{array}{l}\mathbf{0} \\
\mathbf{0} \\
\mathbf{0} \\
\mathbf{0}\end{array}$ & $\begin{array}{l}1 \\
1 \\
1 \\
1\end{array}$ & $\begin{array}{l}0 \\
0 \\
1 \\
1\end{array}$ & $\begin{array}{l}1 \\
1 \\
0 \\
0\end{array}$ & $\begin{array}{l}1 \\
1 \\
1 \\
1\end{array}$ & $\begin{array}{l}\text { no } \\
0 \\
1 \\
0\end{array}$ & $\begin{array}{r}\text { ed } \\
1 \\
0 \\
1\end{array}$ & $\begin{array}{l}\text { no } \\
1 \\
0 \\
0\end{array}$ & $\begin{array}{l}\text { ed } \\
0 \\
1 \\
1\end{array}$ \\
\hline
\end{tabular}


It is reasonable to wonder why diphtheroid bacilli have not been isolated more frequently if they are in any way associated with rheumatoid arthritis. However, the organisms are fastidious and will grow only on blood agar after $\mathbf{4 8}$ hours' incubation, even after repeated subculture on this medium. They are readily detected only on a highly enriched medium, such as that used for the isolation of mycoplasma. Even when such organisms are isolated, they may be discarded as contaminants, as in the early part of this study. It is not surprising that the organisms have not been found by workers culturing specimens for mycoplasma, because media suitable for culture of mycoplasma usually contain penicillin and thallium acetate which would inhibit growth of diphtheroids.

It has not so far been possible to identify the diphtheroids isolated; the group is difficult to study because of its biochemical inactivity.

The results of the present work have not provided decisive evidence of the role of diphtheroid bacilli in the aetiology of rheumatoid arthritis. The evidence suggests that the organisms came from the joints rather than from the environment or culture media, but it is still not possible to say whether they initiate the disease, whether they are low-grade pathogens settling in already damaged tissues, or whether they are innocent bystanders scavanged from the blood by synovial macrophages. Although it is not yet possible to decide which explanation is correct, the phenomenon of isolation of diphtheroids appears to be a reproducible one which, at worst, has to be taken into account as a complication of any attempt to isolate infective agents from rheumatoid synovium and which, at best, may be of aetiological significance.

\section{Summary}

Diphtheroid bacilli, not yet fully identified, were isolated from 21 of 78 specimens of synovial membrane and from twelve of 126 specimens of synovial fluid from patients with rheumatoid arthritis. Three strains were isolated from fifteen fluids from patients with Reiter's disease and one from a patient with possible rheumatoid arthritis. No strains were isolated from twenty membranes and 36 fluids from patients with other articular disorders. Isolations were made most frequently from patients suffering from sero-positive rheumatoid arthritis. There was no correlation between a positive culture and the patient's age or sex or the duration of illness when the specimens were collected.

The possible significance of the recovery of diphtheroid organisms from rheumatoid synovium is discussed.

The authors are grateful to Prof. B. P. Marmion for helpful criticism in the preparation of the manuscript, to Mr. T. Dunn for the electron microscopical study, and to Miss M. White for secretarial assistance. The research work was supported by grants from the Medical Research Council, the Arthritis and Rheumatism Council, and the Nuffield Foundation.

We also wish to acknowledge the co-operation of the surgical team, led by Mr. D. L. Savill, at the Princess Margaret Rose Orthopaedic Hospital, Edinburgh.

The standard strains of Corynebacterium hofmanii, $C$. bovis, $C$. pyogenes, and $C$. xerosis were obtained from the National Collection of Type Cultures, Central Public Health Laboratories, London, N.W.9.

\section{APPENDIX \\ Culture Media}

(1) Eagle Hanks' liquid medium

$\begin{array}{lr}\text { Hanks' medium without } \mathrm{NaHCO}_{3} & 70 \mathrm{ml} \text {. } \\ \text { Eagle medium } \times 10 \text { strength } & 6 \mathrm{ml} \text {. }\end{array}$

Difco tryptose phosphate broth $\quad 10 \mathrm{ml}$.

Serum (unheated swine or human) $20 \mathrm{ml}$.

$\beta$ Diphosphopyridine nucleotide (DPN) 4 per cent.
$1 \mathrm{ml}$.
(2) PPLO Broth (Double strength) Difco PPLO broth base $\times 2$ strength Serum (unheated swine or human) Low temperature yeast extract
$70 \mathrm{ml}$.

$40 \mathrm{ml}$.

$20 \mathrm{ml}$.
Glycerol $0 \cdot 1$ per cent. $\mathrm{NaHCO}_{3} 1.4$ per cent. (saturated with $\mathrm{CO}_{2}$ ) $3 \mathrm{ml}$. Glucose 10 per cent.
$\mathrm{M} / 1 \mathrm{~K}_{2} \mathrm{HPO}_{4}$

DNA 0.2 per cent.

DPN 4 per cent.
$4 \mathrm{ml}$.

$2 \mathrm{ml}$.

$2 \mathrm{ml}$. 
(3) Heated blood liquid medium

$\begin{array}{lllr}\text { Difco PPLO broth base } & 70 \mathrm{ml} . & \text { DNA } 0 \cdot 2 \text { per cent. } & 1 \mathrm{ml} . \\ \text { Horse blood (defibrinated) } & 20 \mathrm{ml} . & \text { DPN } 4 \text { per cent. } & 1 \mathrm{ml} \text {. } \\ \text { Glucose } 10 \text { per cent. } & 10 \mathrm{ml} . & & \end{array}$

This medium was heated to $80^{\circ} \mathrm{C}$. and kept at this temperature until it developed an even chocolate colouration.

\section{(4) Sodium chloride PPLO broth}

Difco PPLO broth plus 2 per cent. $\mathrm{NaCl} 70 \mathrm{ml}$.

Serum (unheated human) $20 \mathrm{ml}$.

Low temperature yeast extract $\quad 10 \mathrm{ml}$.

DNA $0 \cdot 2$ per cent.

DPN 4 per cent.

Glucose 10 per cent.

$1 \mathrm{ml}$.

$1 \mathrm{ml}$.

$10 \mathrm{ml}$.

\section{(5) PPLO agar}

Difco PPLO agar base

Serum (unheated swine or human)

Low temperature yeast extract
$70 \mathrm{ml}$.

$20 \mathrm{ml}$.

$10 \mathrm{ml}$.
$\mathrm{M} / 1 \mathrm{~K}_{2} \mathrm{HPO}_{4}$

DNA $0 \cdot 2$ per cent.

DPN 4 per cent.
$2 \mathrm{ml}$.

$1 \mathrm{ml}$.

$1 \mathrm{ml}$.

\section{(6) Heated blood agar}

Difco PPLO broth base plus $1 \cdot 3$ per cent.

Nobel agar

Horse blood (defibrinated)

Glucose 10 per cent.
$70 \mathrm{ml}$.

$20 \mathrm{ml}$.

$10 \mathrm{ml}$.

The medium was heated as for Medium 3.

\section{(7) Sodium chloride PPLO agar}

Difco PPLO broth base plus $1 \cdot 3$ per cent.

Nobel agar

Serum (unheated human)

Low temperature yeast extract
$70 \mathrm{ml}$.

$20 \mathrm{ml}$.

$10 \mathrm{ml}$.
DNA $0 \cdot 2$ per cent.

DPN 4 per cent.

Glucose 10 per cent.

$1 \mathrm{ml}$.

$1 \mathrm{ml}$.

$10 \mathrm{ml}$.

\section{(8) Bulk medium for testing sterility of human serum}

Difco PPLO broth base

Human serum (unheated)

Low temperature yeast extract

$\mathrm{M} / 1 \mathrm{~K}_{2} \mathrm{HPO}_{4}$
$140 \mathrm{ml}$.

$40 \mathrm{ml}$.

$20 \mathrm{ml}$.

$4 \mathrm{ml}$.

DNA 0.2 per cent.

DPN 4 per cent.

Glucose 10 per cent.
$1 \mathrm{ml}$.

$1 \mathrm{ml}$.

\section{REFERENCES}

Abruzzo, J. L., and Christian, C. L. (1961). J. exp. Med., 114, 791 (The induction of a rheumatoid factor-like substance in rabbits).

Alexander, W. R. M., and McCarthy, D. D. (1966). In "Modern Trends in Rheumatology", ed. A. G. S. Hill, p. 153 . Butterworths, London.

- Stewart, S. M., and Duthie, J. J. R. (1968). In "Rheumatic Diseases" (University of Edinburgh Pfizer Medical Monographs 3), ed. J. J. R. Duthie and W. R. M. Alexander, p. 155. University Press, Edinburgh.

American Rheumatism Association (1959). Ann. rheum. Dis., 18, 49 (Diagnostic criteria for rheumatoid arthritis 1958 revision).

Arai, M., Ishikawa, A., and Hotta, E. (1964). In "Proceedings of the 8th Congress of the Japanese Rheumatism Association", p. 279. Okayama.

Barnett, E. V., Balduzzi, P., Vaughan, J. H., and Morgan, H. R. (1966). Arthr. and Rheum., 9, 720 (Search for infectious agents in rheumatoid arthritis).

Bauer, W., Clark, W. S., and Dienes, L. (1951). Practitioner, 166, 5 (Speculations on the etiology of rheumatoid arthritis).

Bartholomew, L. E. (1965). Arthr. and Rheum., 8, 376 (Isolation and characterization of mycoplasmas (PPLO) from patients with rheumatoid arthritis, systemic lupus erythematosus and Reiter's syndrome).

- (1966). In "Proceedings of the Conference on the Relationship of Mycoplasma to Rheumatoid Arthritis and Related Diseases", p. 160. U.S. Department of Health, Education and Welfare, Bethesda, Maryland. 
- and Himes, J. (1964). Arthr. and Rheum., 7, 291 (Isolation of mycoplasma (PPLO) from patients with rheumatoid arthritis, systemic lupus erythematosus and Reiter's syndrome).

Bradstreet, C. M., and Taylor, C. E. D. (1962). Mthly Bull. Min. Hlth Publ. Hlth Lab. Serv., 21, 96 (Technique of complement-fixation test applicable to the diagnosis of virus diseases).

British Medical Journal (1965) Leader, 1, 607 (Is rheumatoid arthritis an infection?).

Brown, T. McP. Bailey, J. S., Felts, W. R., and Clark, H. W. (1966). Arthr. and Rheum., 9, 495 (Mycoplasma antibodies in synovia).

Cadham, F. T. (1932). Canad. med. Ass. J., 26, 287 (A discussion of the etiology and specific treatment of arthritis).

Christian, C. L. (1961). Arthr. and Rheum., 4, 86 (The possible significance of the "rheumatoid factor").

(1964). Ibid., 7, 455 (Rheumatoid arthritis-etiologic considerations).

Claus, G., McEwen, C., Brunner, T., and Tsamparlis, G. (1964). Brit. J. vener. Dis., 40, 170 (Microbiological studies of Reiter's disease).

Collins, D. H., and Goldie, W., Jr. (1940). J. Path. Bact., 50, 323 (Observations on polyarthritis and on experimental Erysipelothrix infection of swine).

Dayhoff, R. E. (1967). Unpublished observations.

Duthie, J. J. R. (1964). In "Symposium: Polyarthritis, 1963", p. 74. Royal College of Physicians of Edinburgh.

- Alexander, W. R. M., and Stewart, S. M. (1965). In "Proceedings of NATO Conference on Structure and Function of Connective and Skeletal Tissue”, ed. S. Jackson, p. 482. London.

- - Stewart, S. M., Alexander, W. R. M., and Dayhoff, R. E. (1967). Lancet, 1, 142 (Isolation of diphtheroid organisms from rheumatoid synovial membrane and fluid).

Ford, D. K. (1968). Med. Clin. N. Amer., 52, 673 (Evidence for an infectious etiology of rheumatoid arthritis).

— and Oh, J. O. (1965). Arthr. and Rheum., 8, 1047 (Use of "synovial" cell cultures in the search for virus in rheumatoid arthritis).

Hall, A. P. (1961). Med. Clin. N. Amer., 45, 1181 (Serologic tests in rheumatoid arthritis).

Hamerman, D. (1966). Amer. J. Med., 40, 1 (New thoughts on the pathogenesis of rheumatoid arthritis).

Hench, P., and colleagues (1961). In "Rheumatism Reviews (1935-1941)". Excerpta Medica Foundation, Amsterdam.

Hill, A. G. S. (1968). Proc. roy. Soc. Med., 61, 971 (The role of infection in the causation of rheumatoid arthritis).

—, McCormick, J. N., Greenbury, C. L., Morris, C. J., and Kenningale, J. (1967). Ann. rheum. Dis., 26, 566 (Cultivation of micro-organisms from rheumatoid synovia: abstract).

Howell, D. S., Malcolm, J. M., and Pike, R. (1960). Amer. J. Med., 29, 662 (The FII agglutinating factors in serums of patients with non-rheumatoid diseases).

Klieneberger-Nobel, E. (1962). In "Pleuropneumonia-like Organisms (PPLO): Mycoplasmataceae", p. 84. Academic Press, London.

Pinckard, R. N., Weir, D. M., and McBride, W. H. (1968). Clin. exp. Immunol., 3, 413 (Factors influencing the immune response. III. The blocking effect of Corynebacterium parvum upon the induction of acquired immunological unresponsiveness to bovine serum albumin in the adult rabbit).

Ross, R. F., and Switzer, W. P. (1968). Med. Clin. N. Amer., 52, 677 (Mycoplasmal arthritis of swine: a possible model for rheumatoid arthritis).

Sabin, A. B., and Warren, J. (1940). J. Bact., 40, 823 (The curative effect of certain gold compounds on experimental proliferative, chronic arthritis in mice).

Schachter, J. (1967). Amer. J. Ophthal., 63, 1082 (Isolation of Bedsoniae from human arthritis and abortion tissues).

_- Barnes, M. G., Jones, J. P., Engleman, E. P., and Meyer, K. F. (1966). Proc. Soc. exp. Biol. (N.Y.), 122, 283 (Isolation of bedsoniae from the joints of patients with Reiter's syndrome).

Sharp, J. T. (1964). Arthr. and Rheum., 7, 437 (The mycoplasmataceae (PPLO) as causes of joint infections).

and Riggs, S. (1967). Rheumatology (Basel), 1, 51 (Mycoplasmas and rheumatic disease).

Stewart, S. M. (1967). In "3rd Nuffield Conference on Rheumatism, Ditchley Park", p. 191. Nuffield Foundation, London.

Svartz, N. (1961). "Experimental studies on the rheumatoid factor", in "Atti del X Congress della Lega Internazionale contro il Reumatismo, Roma, 1961", vol. 1, p. 57. Minerva Medica, Torino. 
Utz, J. P., Phelps, E. T., and Smith, L. G. (1959). Bull. Georgetown Univ. med. Center, 12, 198 (Rheumatoid arthritis: viral studies of adult human synovial fluid and tissue using tissue culture techniques).

Waller, M., Sever, J., Curry, N., and Gilkeson, M. R. (1966). Ann. rheum. Dis., 25, 327 (Relationship between antiviral antibodies and rheumatoid factor in pregnant women).

Weir, D. M. (1969). Personal communication.

Williams, M. H. (1968). In "Rheumatic Diseases", ed. J. J. R. Duthie and W. R. M. Alexander, (University of Edinbrugh Pfizer Medical Monographs 3), p. 171. University Press, Edinburgh.

Wilson, G. S., and Miles, A. A. (1964). "Topley and Wilson's Principles of Bacteriology and Immunity", 5th ed., vol. 2, p. 1704. Arnold, London.

\section{L'Isolement des bacilles diphtéroïdes de la membrane et du} liquide synoviaux dans la polyarthrite rhumatoìde

\section{RÉsumÉ}

Les bacilles diphtéroïdes qui n'ont pas été encore identifiés ont été isolés de 21 des 78 spécimens de la membrane synoviale et de 12 des 126 spécimens du liquide synovial obtenus des malades atteints de polyarthrite rhumatoìde. Trois souches ont été isolées de 15 liquides de malades atteints de la maladie de Reiter et une d'un malade atteint de polyarthrite rhumatoïde probable. Aucune souche n'avait été isolée de vingt membranes et de trente-six liquides de malades atteints d'autres affections articulaires. L'isolement des bacilles a été fait le plus souvent chez les malades atteints de polyarthrite rhumatoïde donnant une réaction séropositive. Il n'y avait aucune corrélation entre une culture positive et l'âge, le sexe du malade ou la durée de la maladie quand les spécimens ont été obtenus.

La portée de ces résultats est discutée.
Aislamiento de bacilos difteroides de la membrana y fluido sinoviales en la poliartritis reumatoide

\section{SUMARIO}

Bacilos difteroides, no identificados por completo, fueron aislados en 21 de 78 especímenes de membrana sinovial y en 12 de 126 especímenes de fluido sinovial de pacientes con poliartritis reumatoide. Se aislaron tres tipos de quince fluidos de pacientes con síndrome de Reiter y uno de un paciente con posible poliartritis reumatoide. No se aislaron tipos de 20 membranas y de 36 fluidos de pacientes con otros desórdenes articulares. Los aislamientos se realizaron más frecuentemente de pacientes que sufrían de poliartritis reumatoide seropositiva. No hubo correlación entre un cultivo positivo y la edad o sexo del paciente o la duración de la enfermedad cuando fueron obtenidos los especímenes. Se discute el posible significado de la obtención de organismos difteroides de la sinovia reumatoide. 